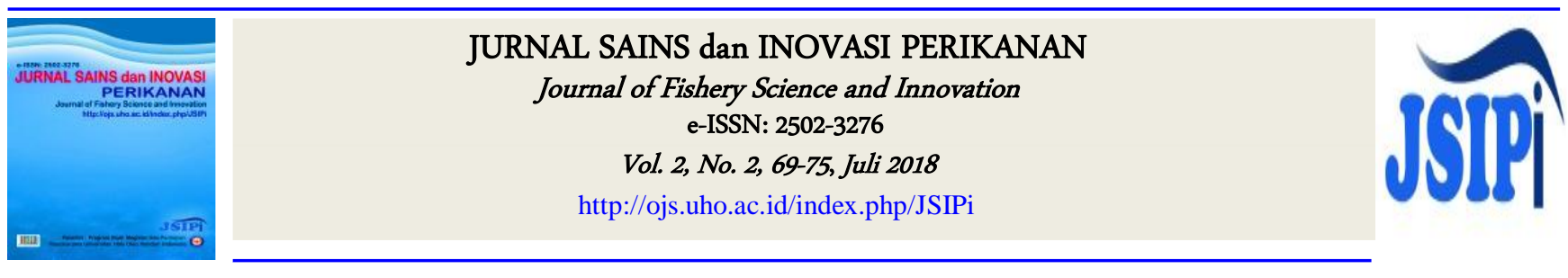

\title{
Pengaruh Suplementasi Kitin Dari Kulit Udang terhadap Profil Darah Ikan Mas (Cyprinus carpio)
}

\section{The Effect of Chitin Enriched Diet on Hematology Profile in Common Carp (Cyprinus carpio)}

\author{
Indriyani Nur ${ }^{1 *)}$, Asnani ${ }^{1)}$,dan Khaidhar Ma'ruf ${ }^{2)}$ \\ 1) Fakultas Perikanan dan Ilmu Kelautan, Universitas Halu Oleo Kendari, Indonesia \\ ${ }^{*}$ Corresponding author: indriyani_nur@uho.ac.id
}

\begin{abstract}
One effort that can be used to control fish disease is by enhancing the immune system. The purpose of this research is utilization of shrimp by-product into chitin extract, then added into enrich diet with different doses in order to improve blood profiles in fish. Carp (initial body weight of $\pm 70 \mathrm{~g} / \mathrm{fish}$ ) were acclimated to the laboratory conditions for a week. After that fish were randomly divided into four groups in three replicates. Each group received chitin in diet at four doses as 0 (control), $0.04 ; 0.08$, and $0.12 \%$. The parameters observed in this experiment were quantification of chitin from shrimp shell extraction and erythrocytes level (blood hematocrit level) after feeding for 30 days. The result showed that shrimp shell extraction resulted to $39.4 \%$ chitin. The research showed that chitin enrich diet can be consumed well. Hematocrit level was higher in all treatments than control with any significance difference. The control group had the lowest hematocrit level of $21 \%$, while the best treatment was the group of fish with $0.04 \%$ chitin in diet with the hematocrit level of $32 \%$. The present study suggests that supplementation of $0.04 \%$ chitin in diets positively enhances erythrocytes in blood representing as fish health.
\end{abstract}

Keywords: Carp (Cyprinus carpio), chitin, haematocrit, shrimp by product

\begin{abstract}
ABSTRAK
Salah satu upaya yang dapat digunakan untuk mengendalikan penyakit yang menyerang ikan yaitu dengan menumbuhkan kekebalan tubuh. Tujuan penelitian ini adalah pemanfaatan limbah kulit udang menjadi ekstrak kitinyang diberikan melalui pengayaan pakan dengan dosis berbeda untuk memperbaiki profil darah pada ikan.Ikan mas (dengan berat awal \pm 70 g/ekor) diaklimatisasi dalam pemeliharaan di laboratorium selama 1 minggu. Setelah itu ikan dibagi secara acak ke dalam empat kelompok perlakuan dengan tiga ulangan. Setiap kelompok diberikan perlakuan pakan yang telah diformulasi dengan penambahan kitin yang telah diekstrak dari kulit udang. Dosis kitin yang diberikan adalah 0 (kontrol), 0.04; 0.08, dan 012\%. Parameter yang diamati dalam penelitian ini adalah kuantifikasi kitin dari hasil ekstraksi kulit udang dan jumlah eritrosit (kadar hematokrit darah)setelah 30 hari pemberian pakan. Ekstraksi kulit udang diperoleh kitin sebesar 39,4\%. Kitin yang dicampurkan dalam pakan dapat dikonsumsi dengan baik oleh ikan mas.Kadar hematokrit menunjukkan peningkatan pada hewan uji yang diberi pakan berkitin dibandingkan kontrol, terdapat perbedaan antar perlakuan $(\mathrm{p}<0.05)$. Kelompok ikan kontrol (tanpa pemberian kitin) memiliki kadar hematokrit terendah yaitu $21 \%$ sedangkan perlakuan terbaik adalah kelompok ikan dengan penambahan kitin $0.04 \%$ dengan kadar hematokrit mencapai $32 \%$. Penelitian ini mengindikasikan potensi kitin dalam meningkatkan eritrosit dalam darah sekaligus menunjukkan kemampuannya dalam meningkatkan kesehatan ikan.
\end{abstract}

Kata kunci: Hematokrit, ikan mas (Cyprinus carpio), kitin, limbah udang

DOI: http://dx.doi.org/10.33772/jspi.v3n1. 
70 Indriyani Nur et al.

JURNAL SAINS dan INOVASI PERIKANAN / Journal of Fishery Science and Innovation

Vol. 2, No. 2, 69-75, Juli 2018

\section{PENDAHULUAN}

Ikan mas (Cyprinus carpio) merupakan salah satu jenis ikan budidaya yang penting dan telah menjadi ikan konsumsi yang digemari oleh masyarakat luas. Oleh karenanya budidaya ikan tersebut berkembang dan produksi selalu ditingkatkan.

Pada beberapa farm budidaya ikan mas mengalami kendala yang cukup serius berupa infeksi penyakit, utamanya yang disebabkan oleh bakteri patogen dan virus. Di Indonesia pertama kali wabah penyakit yang disebabkan bakteri Aeromonas hydrophila terjadi di Jawa Barat pada tahun 1980, menyebabkan kematian 82,2 ton dalam waktu 1 bulan (Angka 2001). Penyakit yang ditimbulkan tersebut MAS (Motile Aeromonas Septicemia), beberapa peneliti lain menyebutnya sebagai penyakit luka merah dan haemorragic septicemia (Adanir and Turutoglu, 2007). Sedangkan penyakit pada ikan mas yang disebabkan oleh virus terutama disebut sebagai KHV (Koi Herpes Virus) dan CNGV (Carp Interstitial Nephritis and Gill Necrosis Virus) (Pikarskyet al., 2004). Di Indonesia KHV mulai menginfeksi ikan pada tahun 2002 di Blitar Jawa Timur dan selanjutnya menyebar ke berbagai daerah lainnya dengan tingkat kematian ikan koi dan ikan mas mencapai $80-95 \%$ (Sunarto et al., 2005).

Pengendalian terhadap penyebab penyakit ikan dengan penggunaan bahan kimia termasuk antibiotik secara berkala diupayakan dikurangi karena bahan tersebut menyebabkan resistensi bakteri disamping berpeluang terhadap kerusakan lingkungan perairan. Selain hal tersebut, mengendalikan penyakit viral dengan antibiotik adalah tidak efektif karena antibiotik bekerja pada jalur metabolisme sel prokaryotik, sedangkan virus tidak memiliki jalur metabolisme sendiri.Dengan demikian perlu dicari alternatif lain dalam pengobatan penyakit ikan untuk perlindungan yang general dan tanpa efek samping.

Indonesia sebagai salah satu negara tropis memiliki keragaman hayati yang tinggi sebagai sumber bahan alami (natural product) yang berasal dari tumbuhan, hewan, dan mikroorganisme. Bahan alami tersebut selain digunakan untuk kepentingan pangan dan papan, juga dimanfaatkan sebagai bahan terapeutik.

Salah satu potensi ini adalah udang yang saat ini merupakan komoditas ekspor unggulan hasil perikanan. Ekspor udang ini selalu meningkat dari tahun ke tahun. Sebagian besar udang diekspor dalam bentuk udang beku tanpa kepala dan kulit. Dengan demikian jumlah hasil samping produksi yang berupa kepala, kulit, ekor maupun kaki udang yang umumnya $35-45 \%$ dari berat, sangat berlimpah (Trung et al., 2012). Di Indonesia limbah tersebut belum dimanfaatkan sekitar 56.200 ton per tahun, bahkan menjadi permasalahan lingkungan (Rochima, 2014). Oleh karenanya diupayakan pemanfaatan limbah ini.

Melalui pendekatan teknologi yang tepat, potensi limbah ini dapat diolah lebih lanjut menjadi senyawa polisakarida (polysaccaride), dimana di dalamnya termasuk kitin $\left[\left(\mathrm{C}_{8} \mathrm{H}_{13} \mathrm{NO}_{5}\right) \mathrm{n}\right]$. Kitin dapat diolah lebih lanjut menjadi kitosan $\left.\left[\mathrm{C}_{6} \mathrm{H}_{11} \mathrm{NO}_{4}\right) \mathrm{N}\right]$ dan glukosamin $\left[\left(\mathrm{C}_{6} \mathrm{H}_{13} \mathrm{NO}_{5}\right)\right]$. Ketiga produk ini mempunyai mudah terurai dan tidak mempunyai sifat beracun, sehingga sangat ramah terhadap lingkungan.

Untuk kitin dan kitosan telah dilakukan beberapa pengujian untuk kemungkinan pemanfaatannya dalam pengendalian penyakit ikan. Harikrishnan et al. (2012) dan Alishahi et al. (2014) menyatakan bahwa kitin dan kitosan memberikan efek immunostimulsi atau dapat menumbuhkan kekebalan tubuh ikan. Selain itu terbukti mengatasi stres pada ikan (Meshkini et al., 2012).

Sehubungan dengan hal di atas, perlu dilakukan penelitian untuk mengkuantifikasi dan mengkaji potensi kitin sebagai upaya pemanfaatan limbah kulit udang untuk meningkatkan kesehatan darah ikan, terutama untuk memperbaiki profil darah ikan. Agar penggunaan kitin dari kulit udang dapat diperoleh dan digunakan dengan tepat maka perlu pengetahuan tentang cara ekstraksi, jumlah dan cara pemberian yang tepat dalam rangka efektifitas dan efesiensi.

\section{METODE PENELITIAN}

\section{Hewan Uji.}

Ikan mas dengan berat +70 gram/ekor diperoleh dari petani di sekitar kota Kendari. Selanjutnya ikan diaklimatisasi dalam pemeliharaan in door laboratorium di bak fiber volume 1 ton selama 1 minggu hingga ikan tidak menunjukkan tanda-tanda stres atau sakit.

\section{Preparasi Kitin.}

Ekstraksi kitindari kulit atau cangkang udang dilakukan berdasarkan metode yang dilaporkan oleh Hartati, et al., (2002); Harikrishnan et al., (2012); dan Pal (2014) yang telah dimodifikasi. Secara umum ekstraksi kitin meliputi tahap deproteinasi, demineralisasi dan proses enzimatik. Kulit udang 
dicuci dengan air bersih sehingga tidak berbau menyengat dan bersih dari serat daging yang menempel. Selanjutnya kulit udang dikeringkan dapat dengan bantuan sinar matahari atau dengan oven suhu $65^{\circ} \mathrm{C}$ selama 48 jam atau hingga kulit tersebut rapuh. Selanjutnya udang dihaluskan dengan blender dan disaring hingga diperoleh serbuk (powder). Tahap mineralisasi dilakukan dengan merendam bubuk kulit udang dengan larutan asam $\mathrm{HCl} 3 \mathrm{~N}$ dengan perbandingan 1:5 (b/v) sambil dipanaskan pada suhu $75^{\circ} \mathrm{C}$ selama 2 jam. Berikutnya larutan $\mathrm{HCl}$ dibuang dengan cara menyaring bubuk kulit udang dan dicuci dengan beberapa kali hingga air cucian mencapai $\mathrm{pH}$ netral. Selanjutnya bubuk tersebut dikeringkan pada suhu $60^{\circ} \mathrm{C}$ selama 4 jam. Tahap berikutnya adalah deproteinasi atau menghilangkan senyawa protein yang ada di kulit udang tersebut. Enzim proteinasi atau ekstrak papain diberikan pada serbuk sebanyak $3 \%$. Kemudian dilakukan pemanasan $80^{\circ} \mathrm{C}$ selama 30 menit sambil terus diaduk dengan tujuan menginaktivasi enzim. Penyaringan dilakukan dilakukan hingga memperoleh filtrat, kemudian dikeringkan pada suhu $60^{\circ} \mathrm{C}$ selama 6 jam. Ekstrak kitin selanjutnya digunakan untuk suplemen dalam pakan ikan.

\section{Pembuatan Pakan.}

Bahan dasar dalam pembuatan pakan terdiri atas berbagai bahan sebagai sumber protein, karbohidrat, lemak, vitamin, dan mineral. Komposisi bahan seperti yang tampak pada Tabel 1. Bahan dicampur merata kemudian ditambahkan air tawar sedikit demi sedikit hingga $\pm 100 \%$ dari bobot bahan dan diaduk kembali. Bahan yang sudah tercampur dan dapat dibentuk sekepalan tangan selanjutnya dikukus selama 5 menit, kemudian dicetak pellet dengan bantuan pencetak pakan (pelletizer). Ukuran pellet dibuat dengan dengan memperhatikan ukuran ikan yang digunakan sebagai ikan uji. Sebagaimana diketahui bahwa pellet idealnya memiliki ukuran yang sesuai dengan bukaan mulut ikan.

Pellet dikeringkan dalam oven dengan suhu 45 $50^{\circ} \mathrm{C}$ pada 6 jam pertama, dan $55-65^{\circ} \mathrm{C}$ untuk 12 jam berikutnya. Pellet kering siap diberikan ke ikan uji atau disimpan dalam wadah tertutup untuk disimpan lama.

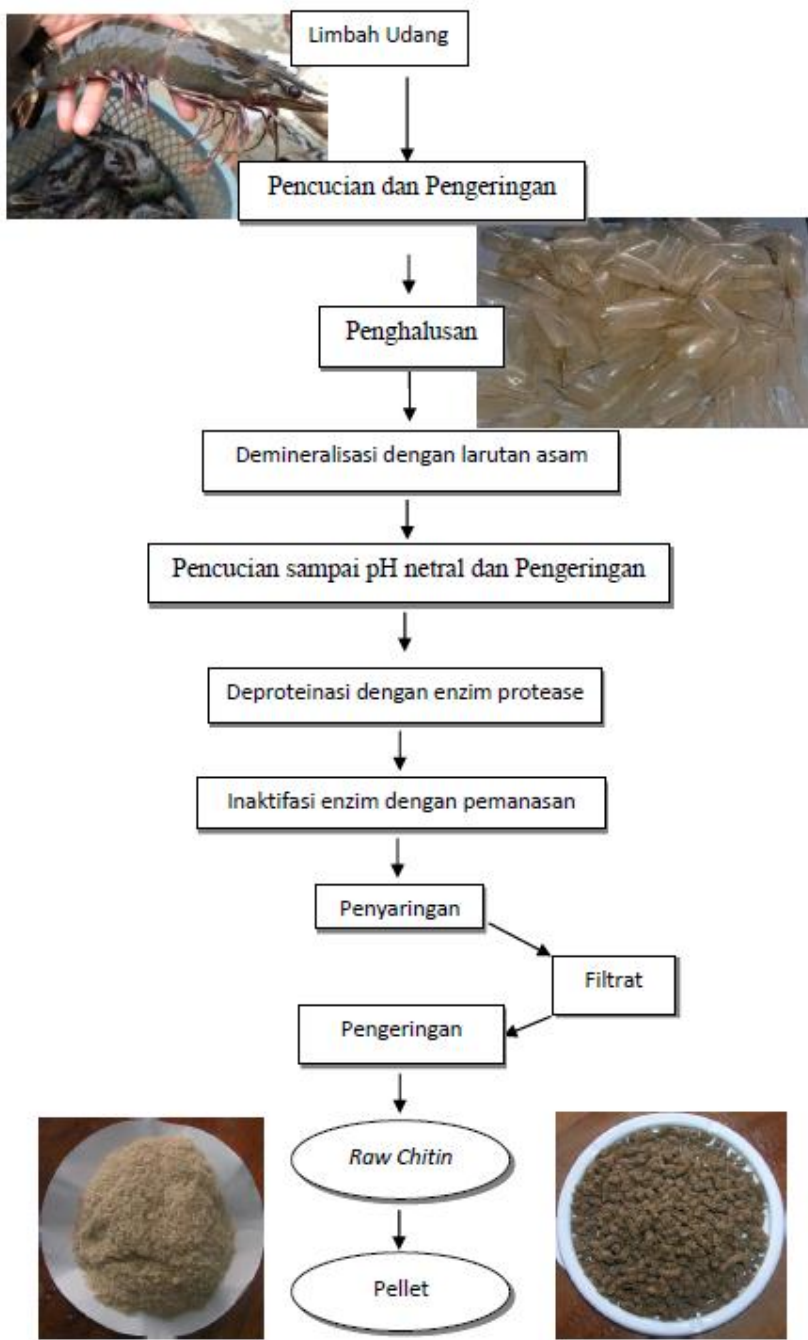

Gambar 1. Prosedur pembuatan pakan ikan dari kulit udang.

\section{Pemeliharaan dan Perlakuan.}

Ikan dipelihara dengan pemberian pakan tersebut di atas dengan jumlah 5\% per bobot tubuh ikan setiap hari dan frekuensi pemberian 2 kali sehari (pagi dan sore hari). Setiap hari dilakukan pergantian air sebanyak $10 \%$ volume air pemeliharaan.Penelitian ini menggunakan Rancangan Acak Lengkap (RAL) dengan 4 perlakuan dan 3 ulangan. Perlakuan adalah penggunaan dosis kitin sebagai berikut: Kitin dalam pakan $0 \mathrm{mg} / \mathrm{kg}$ pakan bertindak sebagai kontrol (A); $40 \mathrm{mg} / \mathrm{kg}$ pakan (B) $80 \mathrm{mg} / \mathrm{kg}$ pakan (C), dan 120 $\mathrm{mg} / \mathrm{kg}$ pakan (D). 
72 Indriyani Nur et al.

JURNAL SAINS dan INOVASI PERIKANAN / Journal of Fishery Science and Innovation

Vol. 2, No. 2, 69-75, Juli 2018

Tabel 1. Komposisi bahan yang digunakan dalam pembuatan pakan uji.

\begin{tabular}{lcccc}
\hline \multirow{2}{*}{ Jenis Bahan } & \multicolumn{4}{c}{ Komposisi Bahan Pakan $(\mathrm{g} / 100 \mathrm{~g})$} \\
\cline { 2 - 5 } & $\mathrm{A}$ & $\mathrm{B}$ & $\mathrm{C}$ & $\mathrm{D}$ \\
\hline Dedak halus & 45 & 45 & 45 & 45 \\
Ampas tahu & 15 & 15 & 15 & 15 \\
Tepung ikan & 30 & 30 & 30 & 30 \\
Minyak ikan & 1 & 1 & 1 & 1 \\
Tepung kanji & 3,7 & 3,7 & 3,7 & 3,7 \\
Mineral \& & & & & \\
Vitamin & 0,3 & 0,3 & 0,3 & 0,3 \\
kompleks & 0 & 0,04 & 0,08 & 0,12 \\
Kitin & 1,000 & 0,960 & 0,920 & 0,880 \\
Agar & & & & \\
\hline Jumlah & 100 & 100 & 100 & 100 \\
\hline
\end{tabular}

\section{Pengukuran level hematokrit (Hct).}

Pada hari ke-30 masa pemeliharaan, dilakukan sampling sebanyak 1 ekor per akuarium untuk analisa hematokrit. Pengambilan darah dilakukan pada vena caudal ikan. Sebelum disuntikan, syringe terlebih dahulu dicuci dengan antikoagulan Na-sitrat 3,8\%. Darah lalu diambil sebanyak $\pm 0,5 \mathrm{ml}$. Pengukuran hematokrit dilakukan dengan prosedur: darah dimasukkan ke dalam tabung kapiler. Setelah mencapai $3 / 4$ panjang tabung, salah satu ujungnya ditutup dengan creatoseal. Selanjutnya disentrifuse dengan kecepatan 3500 rpm selama 4 menit dengan alat mikrosentrifuse. Pengukuran hematokrit dilakukan dengan membandingkan antara volume darah merah terhadap volume seluruh darah dan dinyatakan dalam persen.

Analisis Data. Data kadar hematokrit pada setiap perlakuan diuji dengan analisa ragam (ANOVA) dilanjutkan dengan uji lanjut Beda Nyata Terkecil (LSD) untuk mengetahui perbedaan antar perlakuan menggunakan software SPSS 11.5.

\section{HASIL DAN PEMBAHASAN}

\section{Hasil}

\section{Ekstrak Kitin dari Kulit Udang}

Dari kegiatan ekstraksi kitin yang dilakukan diperoleh kitin sebanyak 39,4\% dari kulit udang yang telah kering dan dihaluskan. Jumlah ini sependapat dengan Pal et al., (2014) bahwa kulit udang mengandung kitin 15\% - 40\%. Namun dijelaskan lebih lanjut bahwa kandungan kitin juga bervariasi bergantung pada jenis udang dan tempat hidupnya.
Walaupun ekstraksi kitin yang dilakukan pada penelitian ini telah dilakukan sesuai dengan prosedur standar, namun kitin yang diperoleh masih cenderung tinggi. Relatif tinggi kadar kitin yang diperoleh dalam penelitian ini dimungkinkan karena tahapan demineralisasi dan deproteinasi kurang berlangsung dengan baik sehingga kitin belum murni atau masih terdapat protein dan mineral yang terikut. Salah satu kekurangan dalam penelitian ini adalah tidak dilakukannnya pengujian kemurnian kitin hasil ekstraksi.

Kitin hasil ekstraksi memiliki penampilan berwarna putih kecoklatan, berupa serbuk halus kering. Menurut Hardjito (2006), agar kitin berwarna putih bersih maka digunakan pemutih dalam pembuatannya. Namun karena kitin yang digunakan dalam penelitian akan dicampurkan dalam pakan maka dianggap tidak perlu hingga berwarna putih bersih. Kitin yang diperoleh kemudian disimpan dalam wadah tertutup dan ditaruh di tempat yang tidak lembab. Hal ini untuk memperpanjang masa simpan kitin dan menjaga agar tidak ditumbuhi jamur sehingga dapat digunakan dalam waktu yang lama.

\section{Kadar Hematokrit}

Dari hasil penelitian diketahui bahwa rata-rata kadar hematokrit pada ikan mas teringgi terdapat pada perlakuan dengan penambahan kitin $0.04 \%$ atau 40 $\mathrm{mg} / \mathrm{kg}$ pakan yakni level hematokrit sebesar $32,33 \%$. Nilai hematokrit terendah terdapat pada perlakuan tanpa penambahan kitin yaitu $21,67 \%$.

Dari hasil sidik ragam diperoleh bahwa dosis kitin yang berbeda memberikan pengaruh nyata terhadap kadar hematokrit ikan mas. Kemudian dari uji lanjut LSD diketahui bahwa kontrol berbeda nyata dengan perlakuan B atau perlakuan dengan penambahan kitin $40 \mathrm{mg} / \mathrm{kg}$ pakan tetapi kontrol tidak berbeda bila dibandingkan dengan perlakuan lainnya. Kemudian perlakuan penambahan kitin lainnya yaitu perlakuan B, C dan D tidak berbeda nyata. Kadar hematokrit pada ikan uji dapat dilihat pada Tabel 2. 
JURNAL SAINS dan INOVASI PERIKANAN / Journal of Fishery Science and Innovation Vol. 2, No. 2, 69-75, Juli 2018

Tabel 2. Kadar rata-rata kematokrit pada ikan mas yang diberi kitin dalam pakan.

\begin{tabular}{cc}
\hline Perlakuan & $\begin{array}{c}\text { Kadar Hematokrit Darah }(\%) \\
(\text { rata-rata } \pm \text { SD) }\end{array}$ \\
\hline A & $21,67 \pm 3,51^{\mathrm{b}}$ \\
B & $32,33 \pm 2,51^{\mathrm{a}}$ \\
C & $30,67 \pm 4,50^{\mathrm{ab}}$ \\
D & $23,00 \pm 9,17^{\mathrm{ab}}$ \\
\hline
\end{tabular}

\section{Pembahasan}

Kitin merupakan derivat polisakarida yang telah terbukti bertindak sebagai immunostimulan bukan hanya pada manusia (Li et al., 2013) dan hewan terestrial (Li et al., 2015; Nur and Pagala, 2014), namun juga pada biota akuakultur (Maqsood et al., 2011; Mastan, 2015). Salah satu cara mengindikasikan bekerjanya immunostimulan adalah dengan mengamati hematology, termasuk kadar hematokrit dan leukosit (Barman et al., 2013).

Hematokrit berhubungan dengan jumlah sel darah merah dengan plasma darah. Oleh karenanya hematokrit dapat digunakan untuk mendeteksi anemia pada ikan. Status kesehatan pada penelitian penambahan kitin dalam pakan yang diberikan pada ikan mas memperlihatkan gejala yang cukup baik. Terbukti dari kadar hematokrit yang dicapai pada ikan uji berkisar antara $23-32 \%$ sedangkan pada kelompok kontrol atau tanpa penambahan kitin hanya mencapai $21 \%$. Dari beberapa hasil penelitian lain yang mengukur hematokrit ikan antara lain Abedi et al., (2013) dan Hossain et al., (2014) menyatakan bahwa normalnya kadar hematokrit pada ikan mas berkisar $25-52 \%$, semakin rendah kadar hematokrit mengindikasikan ikan stres atau adanya penyakit anemia ataupun infeksi. Ali dan Ansari (2013) membandingkan Hct ikan mas yang sehat dan dan ikan yang terinfeksi parasit monogenea. Diketahui bahwa Hct ikan mas sehat sejumlah $\pm 27 \%$, sedang yang ikan terinfeksi yaitu $\pm 18 \%$.

Dalam penelitian ini ternyata pemberian kitin pada dosis yang lebih tinggi tidak memperlihatkan kecenderungan peningkatan level hematokrit yang lebih tinggi pula. Perlakuan dosis rendah pada penelitian ini $(0.04 \%)$ justru yang menunjukkan peningkatan sel darah merah (eritrosit) yang tertinggi, perlakuan dosis kitin yang lebih tinggi juga mengakibatkan peningkatan level hematokrit namun secara statistik tidak berbeda jika dibandingkan kelompok kontrol. Hal ini menunjukkan bahwa kemampuan kitin dalam menstilmulasi pembentukan sel darah merah dibatasi oleh dosis. Jika terlalu banyak bisa mengakibatkan immunosuppressive atau menekan munculnya efek stimulasi.

Sel darah merah berhubungan dengan transport oksigen dan aktifitas pertahanan tubuh. Rangsangan imun dengan penambahan kitin dapat dilihat dari beberapa parameter termasuk diantaranya adalah kadar dan komposisi darah meliputi jumlah leukosit, eritrosit dan haemoglobin (Harikrishnan et al., 2012). Jika pemberian kitin mampu merangsang pembentukan sel-sel imun (terutama imunitas non spesifik) yang kemudian dilepaskan dalam darah maka aktifitas fagositik data berjalan dengan baik. Oleh karenanya mampu mempertahankan tubuh ikan terhadap infeksi patogen (Mastan, 2015).

Kemampuan kitin dalam meningkatkan sistem kekebalan tubuh diakibatkan kemiripan struktur molekul kitin dengan membran sel. Oleh karenanya sangat menguntungkan pada kekebalan humoral dan sel, terutama karena kemampuannya sebagai stimulan pada produksi interferon (suatu protein kecil yang menghambat pertumbuhan virus), dan interleukin (suatu protein yang memainkan peranan penting dalam aktivasi sel limfosit $\mathrm{T}$ dan $\mathrm{B}$ ) bila terdapat antigen atau bahan asing ke dalam tubuh. Kesimpulannya, kadar hematokrit yang meningkat setelah pemberian kitin $0.04 \%$ pada ikan mas, mengindikasikan kesiapan untuk mengendalikan infeksi patogen. Olehnya memanfaatkan limbah udang dianjurkan untuk keberlangsungan akuakultur.

Ucapan Terima Kasih : Ucapan terimakasih disampaikan kepada Direktorat Pendidikan Tinggi atas bantuan dana sehingga penelitian ini terlaksana.

\section{DAFTAR PUSTAKA}

Abedi Z, Khalesi MK, Eskandari SK. 2013. Biochemical and hematological profiles of common carp (Cyprinus carpio) under sublethal effects of trivalent chromium. Iranian Journal of Toxicology 7(20): 782-792.

Adanir R, Turutoglu H. 2007. Isolation and antibiotic susceptibility of Aeromonas hydrophila in a carp (Cyprinus carpio) Hatchery Farm Dilek Ozturk. Bull. Vet. Inst. Pulawy 51: 361-364

Ali H, Ansari KK. 2012. Comparison of haematologial and biochemical indices in healthy and monogenean infected common carp, Cyprinus 
74 Indriyani Nur et al.

JURNAL SAINS dan INOVASI PERIKANAN / Journal of Fishery Science and Innovation

Vol. 2, No. 2, 69-75, Juli 2018

carpio. Annals of Biological Research 3 (4):18431846.

Alishahi M, Esmaeili RE, Zarei M, Ghorbanpour M. 2014. Effect of dietary chitosan on immune response and disease resistance in Cyprinus carpio. Iranian Journal of Veterinary Medicine 8(2):125-133.

Angka SL. 2001. Studi karakterisasi dan patologi Aeromonas hydrophila pada ikan lele dumbo (Clarias gariepinus). Makalah Falsafah Sains, Program Pasca Sarjana. Institut Pertanian Bogor. http://www.hayati-

ipb.com/users/rudyct/PPs702/Angka.htm. Oktober 2014].

Barman D, Nen P, Mandal SC, Kumar V. 2013. Immunostimulants for aquaculture health management. J. Marine Sci. Res. Dev. 3: 134.

Hardjito L. 2006. Chitosan sebagai bahan pengawet pengganti formalin. Jurnal Pangan 46(15): 80-84.

Harikrishnan R, Kim J, Balasundaram C, Heo M. 2012. Dietary supplementation with chitin and chitosan on haematology and innate immune response in Epinephelus bruneus against Philasterides dicentrarchi. Experimental Parasitology 131: 116-124.

Hartati FK, Susanto T, Rakhmadiono S, Loekito AS. 2002. Faktor-faktor yang berpengaruh terhadap tahap deproteinase menggunakan enzim protease dalam pembuatan kitin dari cangkang rajungan (Portunus pelagicus). Biosain 2(1): 68-77.

Hossain S, Sharmin S, Haque MA, Shahjahan M. 2014. Hematological changes in common carp exposed to sub-lethal concentrations of sumithion. Proceedings of 5th International Conference on Environmental Aspects of Bangladesh [ICEAB]. pp. 104-106.

Li T, Na R, Yu P, Shi B, Yan S, Zhao Y, Xu Y. 2015. Effects of dietary supplementation of chitosan on immune and antioxidative function in beef cattle. Czech J. Anim. Sci. 60(1): 38-44.

Li X, Min M, Du N, Gu Y, Hode T, Naylor M, Chen D, Nordquist RE, Chen WR. 2013. Chitin, chitosan, and glycated chitosan regulate immune responses: the novel adjuvants for cancer vaccine. Journal of Clinical and Developmental Immunology 1-8. doi:10.1155/2013/387023.

Mastan SA. 2015. Use of immunostimulants in aquaculture disease management. International Journal of Fisheries and Aquatic Studies, 2(4): 277-280
Maqsood S, Singh P, Samoon MH, Munir K. 2011. Emerging role of immunostimulants in combating the disease outbreak in aquaculture. International Aquatic Research 3: 147-163.

Meshkini S, Tafy A, Tukmechi A, Farhang-Pajuh. 2012. Effects of chitosan on hematological parameters and stress resistance in rainbow trout (Oncorhynchus mykiss). Veterinary Research Forum 3(1): 49-54.

Nur I, Pagala MA. 2014. Pemanfaatan limbah cangkang udang sebagai "Fat Magnet" pada itik. Prosiding. Memantapkan Indonesia sebagai negara maritim yang tangguh, Kendari 22-23 Maret 2014. pp. 283-288.

Paoletti MG, Norberto L, Cozzarini E, Musumeci S. 2009. Role of chitinases in human stomach for chitin digestion: amcase in the gastric digestion of chitin and chit in gastric pathologies. In: Binomium Chitin-Chitinase: Recent Issues. Editor: Salvatore M, Paoletti MG (Eds.) Nova Science Publishers, Inc. : 339-358.

Pal PJ, Verma HO, Munka VK, Maurya SK, Roy D, Kumar J. 2014. Biological method of chitin extraction from shrimp waste an eco-friendly low cost technology and its advanced application. International Journal of Fisheries and Aquatic Studies 1(6): 104-107.

Pikarsky E, Ronen A, Abramowitz J, Levavi-Sivan B, Hutoran M, Shapira Y, Steinitz M, Perelberg A, Soffer D, Kotler M. 2004. Pathogenesis of acute viral disease induced in fish by carp interstitial nephritis and gill necrosis virus. J Virol. 78(17): 9544-51.

Rochima E. 2014. Kajian pemanfaatan limbah rajungan dan aplikasinya untuk bahan minuman kesehatan berbasis kitosan-Review. Jurnal Akuatika V(1): 71-82.

Sabrina Hossain S, Sharmin S, Haque MA, Shahjahan M. 2014. Hematological changes in common carp exposed to sub-lethal concentrations of sumithion. In: Proceedings of 5th International Conference on Environmental Aspects of Bangladesh [ICEAB 2014]: 104-106.

Sunarto A, Rukyani A, Itami T. 2005. Indonesian experience on the outbreak of koi herpesvirus in koi and carp (Cyprinus carpio). Bull. Fish. Res. Agen. (Suppl. 2): 15-21.

Trung TS, Phuong PTD. 2012. Bioactive compounds from by-products of shrimp processing industry in 
Indriyani Nur et al.

JURNAL SAINS dan INOVASI PERIKANAN / Journal of Fishery Science and Innovation

Vol. 2, No. 2, 69-75, Juli 2018

Vietnam. Journal of Food and Drug Analysis 20

(Suppl. 1): 194-197. 